\title{
Relevant aspects of human toxoplasmosis
}

Katia Denise S Bresciani ${ }^{1 *}$, André Luiz B Galvão ${ }^{2 \dagger}$, Amanda L de Vasconcellos ${ }^{2 \dagger}$, José Antonio Soares ${ }^{3 \dagger}$, Lucas Vinicius Shigaki de Matos $^{2 \dagger}$, Julia Cestari Pierucci ${ }^{2 \dagger}$, Luiz da Silveira Neto ${ }^{2 \dagger}$, Tercilia Oliveira Rodrigues ${ }^{1 \dagger}$, Italmar Teodorico Navarro ${ }^{4 \dagger}$, Jancarlo Ferreira Gomes $^{5}$ and Alvimar J da Costa ${ }^{2+}$

*Correspondence: bresciani@fmva.unesp.br

tThese authors contributed equally to this work.

'UNESP, Universidade Estadual Paulista Julio de Mesquita Filho, Faculdade de Medicina Veterinária de Araçatuba, Araçatuba, São

Paulo, Brazil.

${ }^{2}$ UNESP, Universidade Estadual Paulista Julio de Mesquita Filho, Faculdade de Ciências Agrárias e Veterinárias, UNESP, Jaboticabal, São Paulo, Brazil.

${ }^{3} \mathrm{FKB}$, Fundação Karnig Bazarian, Faculdades Integradas de Itapetininga, Itapetininga, São Paulo, Brazil.

${ }^{4}$ UEL, Universidade Estadual de Londrina, Centro de Ciências Biológicas, Londrina, Paraná, Brazil.

${ }^{5}$ UNICAMP, Universidade Estadual de Campinas, Institutos de Biologia e Computação, Campinas, São Paulo, Brazil.

\begin{abstract}
Considering the great importance that the infection by Toxoplasma gondii has in public health, the aim of this article was to demonstrate some aspects about this disease in human being. This parasite can cause several behavioral changes and many cases of reactivation of this disease are associated with Acquired Immunodeficiency Syndrome - AIDS. Major cases of human infections by T. gondii are assymptomatic and the main clinical manifestation in the acute phase of this zoonosis is lymphadenopathy, usually in the cervical area. There may also be fever, night sweats, myalgia, maculopapular rash lymphocytic atypia and chorioretinitis. The congenital and/or acquired chronic latent cerebral toxoplasmosis play an important role in the development of some types of neurodegeneration, like Alzheimer disease and Down Syndrome. Humans and animals should not consume raw or undercooked meat, unpasteurized or not boiled dairy products, water without being treated and poorly washed fruits and vegetables. Educational programs focused on reducing T. gondii environmental contamination are essential for the congenital infection control. Due to the severity of this kind of infection and its sequel, it is critical that those responsible for the community's health establish prevention programs to avoid such a situation, obtaining results in the medium and long term, and particularly preserving the involved population's welfare. A lack or incomplete prenatal treatment was identified as an important risk factor for congenital toxoplasmosis, reinforcing the need of improvement of prenatal care. In this study was demonstrated the importance of implementing prevention programs to guide pregnant women to prevent the infection. Preventive measures like information and health education; screening of pregnant women and infants; limiting harm from risk behaviour; treatment of risk cases and vaccination are recommended. Serum monitoring throughout pregnancy, so as detect cases of maternal seroconversion allowing for early maternal treatment is also basic. Some countries have adopted control programs of human toxoplasmosis, however, this issue should be of world attention, considering its relevant aspects of public health, requiring the establishment of community education campaigns and monitoring of pregnant women in the pre and neonatal, especially in a preventive action to reduce the pathogenic effects of this disease.
\end{abstract}

Keywords: Toxoplasma gondii, public health, parasitic control, congenital infection

\section{Introduction}

Toxoplasma gondii has great importance in public health. Women in initial stages of gestation may undergo miscarriage, premature birth, neonatal death and even the classical Sabin's Triad, characterized by retinochoroiditis, cerebral calcifications, hydrocephaly or microcephaly $[\mathbf{1 , 2}]$.

This parasite can cause behavioral changes [3] and during pregnancy cases of antenatal depression and anxiety have been related [4-7].

Many cases of reactivation of this disease are associated with Acquired Immunodeficiency Syndrome - AIDS, including pregnant women [8], especially with brain abscess manifestation [9-11].

Educational programs focused on reducing T. gondii environ- mental contamination are essential for the congenital infection control $[7,12,13]$.

\section{Human toxoplasmosis}

Major cases of human infections by T. gondii are assymptomatic and the main clinical manifestation in the acute phase of this zoonosis is lymphadenopathy, usually in the cervical area. There may also be fever, night sweats, myalgia, maculopapular rash lymphocytic atypia [14] and also chorioretinitis [11].

In primary infection of immunocompetent patients, microgranulomas with no necrosis of giant cells, in cases of cervical lymphadenopathy, can be observed.

In hosts with immune deficiency, neonates and the ones infected by the protozoan during intrauterine life, the findings

(C) 2013 Bresciani et al; licensee Herbert Publications Ltd. This is an Open Access article distributed under the terms of Creative Commons Attribution License (http://creativecommons.org/licenses/by/3.0). This permits unrestricted use, distribution, and reproduction in any medium, provided the original work is properly cited. 
Bresciani et al. Research Journal of Infectious Diseases 2013,

may include necrotizing meningoencephalitis and systemic aggravation. Lymphadenopathy-type Piringer Kuchinka and encephalitis were particularly evident [15].

The continued $T$. gondii tachyzoites proliferation and tissue destruction can occur in fetal brain even when there is a marked maternal immune response including maternal $\lg$ [16].

Patients with autism spectrum disorders (ASD) and with chronic toxoplasmosis have persistent neuroinflammation, hypercytokinemia with hypermetabolism associated with enhanced lipid peroxidation, and extreme changes in the weight resulting in obesity [17].

The congenital and/or acquired chronic latent cerebral toxoplasmosis play an important role in the development of some types of neurodegeneration, like Alzheimer disease and Down Syndrome [18].

The intermediate hosts, humans and animals, can acquire the disease by eating raw or undercooked meat, infected with tissue cysts, as well by the consumption of raw vegetables and water contaminated with oocysts [19]. Tachyzoites of $T$. gondii can be acquired by consuming unpasteurized milk, eggs, blood transfusion, semen, organ transplantation, laboratory accidents with biological material and by transplacental via [14,19-24].

In its cycle, the protozoan shows two evolutionary forms in the intermediate host: tachyzoites, structures of rapid multiplication present in organic fluids in the acute phase, and bradyzoites, confined in tissue cysts, especially in the central nervous system and muscles, in the chronic infection. Oocysts, the final product of sexual reproduction, are formed only in the digestive tract of felids, definitive hosts that shed the oocysts with their feces, where by means of sporogony they become infective and extremely resistant to environmental conditions [19,25-27].

The cats are probably the main sources of environmental contamination, because, when infected, they release large quantities of oocysts, allowing the continuity of the parasite biological cycle [23]. Our research group noticed that T. gondii oocysts are widely distributed on the soil of elementary public schools in our region, likely constituting the main contamination source for these children [12]. It was observed that cat owners in a cohort of middle-aged UK women do not have an increased risk of brain cancer, when compared with non-cat owners [28].

Cases of enhanced maternal-fetal transmission of $T$. gondii infection of HIV-infected women chronically infected were described, which may have important public health consequences, considering the increasing frequency of HIVinfection observed among human being around the world [8].

The prevalence of 3599 samples of the National Health Survey 2000 (NHS-2000) and 2916 of the National Health and Nutrition Survey 2006 (NHNS-2006) serum banks, obtained from 1-98 year old subjects of both genders and all states of Mexico was studied. Anti-T. gondii IgG antibodies were determined by ELISA and confirmed by western blot. National crude prevalence was $60.1 \%$ and $62.6 \%$ for NHS-2000 and NHNS-2006, respectively [29].

All soldiers before being deployed in jungle operations should be tested for T. gondii antibodies and to receive adequate health information about the routine use of personnel filters to purify their water for consumption [13].

The tachyzoite, reaches the fetus by transplacental via, causing different levels of damage severity, depending on the virulence and/or lineage, on the strain of the mother's immune response capacity and on the gestational period that the woman presents, that can result, even, in fetal death or severe clinical manifestations. Toxoplasmosis may manifest months or even years later in children born with this parasitosis and in these cases the most common manifestations are retinocorioidite, cerebral calcifications, neuropathies and microcephaly [4].

Studies demonstrated that chorioretinitis affected $18.9 \%$ of children suffering from congenital toxoplasmosis despite antenatal and neonatal screening associated with early treatment. Long-standing follow-up is needed because the first lesion can occur as late as 12 years after birth. Late lesions were less often macular but nevertheless caused sometimes visual impairment [6].

The demonstration of the occurrence of human toxoplasmosis associated to the milk ingestion from proven infected goats, is particularly important in rural and periurban areas where these animals are raised for the purpose of production of milk for domestic consumption [30].

Contamination of municipal water reservoirs with a significant amount of T. gondii oocysts can lead to epidemics, as recorded in Canada, in 1995, or trigger outbreaks like the one reported in 2001, in Santa Isabel do Ivaí, Paraná State, Brazil $[31,32,33]$.

\section{Control of human toxoplasmosis}

Humans and animals should not consume raw or undercooked meat, unpasteurized or not boiled dairy products, water without being treated and poorly washed fruits and vegetables [34]. Meat products from ovine and swine are more contaminated with this parasite cysts, and these are rarely found in bovine $[9,14]$.

Monitoring of Toxoplasma infection in animals destined for human consumption is a great challenge for human toxoplasmosis prevention. In Spain, some people eat horse meat and it was observed that many horses from various regions of the country are serologically positive for toxoplasmosis [35]. It was showed the impossibility of any serological test asserting the absence of $T$. gondii in meat and guarantee that undercooked lamb can be consumed without risk for people [36,37].

As daily routine, the cleaning of catteries, with fecal material removal is indicated, since, in dependence on the environmental conditions, the T. gondii oocysts eliminated 
by cats require at least 24 hours to sporulate and become infectious. It is also important to cover or encircle sand tanks for children recreation, especially when they are not in use, to prevent the cats access $[12,33]$.

Dishes and utensils should be washed with hot water after contact with unwashed fruits, vegetables, unpasteurized milk and seafood. Pregnant women and immunosuppressed individuals need to wear gloves to get contact with the soil or dumps, avoiding possible touches in cat feces [34].

A lack or incomplete prenatal treatment was identified as an important risk factor for congenital toxoplasmosis, reinforcing the need of improvement of prenatal care in Brazil [5]. A 2009 survey in the United States showed that 87.7\% counsel patients about how to prevent toxoplasmosis [38].

In our studies, were interviewed 85 teachers about toxoplasmosis and $67.06 \%(57 / 85)$ did not know about this issue. Interviews were made with 30 teachers of 18 educators from local elementary schools in Brazil and $28.33 \%$ did not know anything about the topic [32]. One hundred and thirty four elderly people, from the institutions, were interviewed and $86.57 \%(116 / 134)$ were ignorant of the dissemination ways [39]. There is a need of implanting programs of control against human toxoplasmosis [39-43].

It's important to reinforce the importance of sanitation control in industrial restaurants and also demonstrate the need for improvement in quality control regarding vegetables at risk for T. gondii oocyst contamination [44].

Strategies to work on muscle fluids offers a great potential for toxoplasmosis studies on farm animals, especially for large scale control studies. We cannot yet offer any serological test asserting the absence of Toxoplasma in meat and offering the guarantee that undercooked lamb can be consumed without posing an unacceptable risk for people at risk and freezing the meat remains necessary $[36,37]$.

Prenatal screening is performed in Austria, France and Slovenia and neonatal screening in the New England states of the USA, parts of Brazil, Denmark and Ireland, but on-demand examination for $T$. gondii antibodies are widely practiced in many European countries [45].

Since 1975, in Austria, serological monitoring of pregnant negative women until the third month of pregnancy it is mandatory, and for suspected cases, treatment is performed until four months of pregnancy with spiramycin and piimetamina associated with sulfadiazine after three months and three weeks $[45,46]$.

In France, since 1978, T. gondii tests were established in seronegative women. However, control measures are not standardized in this country, and so there are divergence between treatment protocols and diagnostic interpretation of infection [47].

In some American states, only serological monitoring of newborns for Toxoplasma lgM has been preconized, without prenatal intervention [48]. The Guidelines for Prevention and Treatment of Opportunistic Infections in HIV-Infected Adults and Adolescents, produced by Centers for Disease Control and Prevention, National Institutes of Health, and HIV Medicine Association of the Infectious Diseases Society of America, contains detailed recommendation $[49,50]$.

Considering the high prevalence of HIV infection in the Kyrgyz Republic, personalized medical orientation as well as treatment and prevention of T. gondii infection are recommended, with special attention to health education for those with lower economic and social status and less access to information [51].

In Spain, due to the low incidence of toxoplasmosis in pregnant women, there is no proper disease control recommendation from health authorities, however, detailed control program has been preconized by the Spanish Society of Pediatric Infectious Diseases for the diagnosis and treatment of congenital toxoplasmosis [52].

Early detection with repeated sorological examination and the treatment of pregnant women can reduce the risk of infection by $T$. gondii as observed in India [53].

Pregnant women in Al Hasas, Saudi Arabia, are substantially vulnerable to toxoplasmosis infection because have no sufficient knowledge for primary prevention of congenital toxoplasmosis [54].

The most commonly therapy is the combination of pyrimethamine and sulfadiazine and folinic acid [55]. In Germany, spiramycin is given until the 16th week of pregnancy, followed by at least 4 weeks of combination therapy with pyrimethamine, sulfadiazine, and folinic acid independent of the infection stage of the fetus and this treatment program was efficient in mimimize transplacentary parasitic transmission [56].

As future perspectives, vaccines development studies against $T$. gondii have demonstrated that heterologous DNA priming and recombinant adenovirus boost strategy may provide protective immunity against $T$. gondii infection [57] and multiantigenic DNA antigen pGRA7-ROP1 was more effective in stimulating host protective immune responses than separately injected single antigens, and that IL- 12 serves as a good DNA adjuvant [58].

It was possible to show the importance of implementing prevention programs to guide pregnant women to prevent the infection. Preventive measures like information and health education; screening of pregnant women and infants; limiting harm from risk behaviour; treatment of risk cases and vaccination are recommended [38]. Serum monitoring throughout pregnancy, so as detect cases of maternal seroconversion allowing for early maternal treatment is also basic $[7,10]$.

\section{Conclusions}

Some countries have adopted control programs of human toxoplasmosis, however, this issue should be of world attention, considering its relevant aspects of public health, requiring the establishment of community education campaigns and 
monitoring of pregnant women in the pre and neonatal, especially in a preventive action to reduce the pathogenic effects of this disease.

List of abbreviations

AIDS: Acquired Immunodeficiency Syndrome

T. gondii: Toxoplama gondii

HIV: Human Immunodeficiency virus

Competing interests

The authors declare that they have no competing interests.

Authors' contributions

\begin{tabular}{|l|c|c|c|c|c|c|c|c|}
\hline $\begin{array}{l}\text { Authors' } \\
\text { contributions }\end{array}$ & KDSB & ALBG & ALV & LVSM & JCP & JAS & JFG & AJC \\
\hline $\begin{array}{l}\text { Research con- } \\
\text { cept and design }\end{array}$ & $\sqrt{ }$ & $\sqrt{ }$ & $\sqrt{ }$ & - & -- & - & - & -- \\
\hline $\begin{array}{l}\text { Collection and/ } \\
\text { or assembly of } \\
\text { data }\end{array}$ & $\sqrt{ }$ & $\sqrt{ }$ & $\sqrt{ }$ & $\sqrt{ }$ & $\sqrt{ }$ & $\sqrt{ }$ & $\sqrt{ }$ & $\sqrt{ }$ \\
\hline $\begin{array}{l}\text { Data analysis and } \\
\text { interpretation }\end{array}$ & $\sqrt{ }$ & $\sqrt{ }$ & $\sqrt{ }$ & $\sqrt{ }$ & $\sqrt{ }$ & $\sqrt{ }$ & $\sqrt{ }$ & $\sqrt{ }$ \\
\hline $\begin{array}{l}\text { Writing the } \\
\text { article }\end{array}$ & $\sqrt{ }$ & $\sqrt{ }$ & $\sqrt{ }$ & $\sqrt{ }$ & $\sqrt{ }$ & $\sqrt{ }$ & $\sqrt{ }$ & $\sqrt{ }$ \\
\hline $\begin{array}{l}\text { Critical revision } \\
\text { of the article }\end{array}$ & $\sqrt{ }$ & $\sqrt{ }$ & $\sqrt{ }$ & - & -- & -- & -- & -- \\
\hline $\begin{array}{l}\text { Final approval of } \\
\text { article }\end{array}$ & -- & -- & -- & -- & -- & -- & -- & -- \\
\hline $\begin{array}{l}\text { Statistical } \\
\text { analysis }\end{array}$ & -- & -- & -- & -- & -- & -- & -- & -- \\
\hline
\end{tabular}

Acknowledgement and funding

To FAPESP for the financial support for this publication.

Publication history

EIC: Ishtiaq Qadri, King Abdul Aziz, University, Jeddah, Saudi Arabia. Editor: Claudio A. Pereira, University of Buenos Aires, Argentina.

Received: 12-Jun-2013 Revised: 20-Aug-2013

Accepted: 02-Sep-2013 Published: 19-Sep-2013

\section{Reference}

1. Jones JL, Kruszon-Moran D, Wilson M, McQuillan G, Navin T and McAuley JB. Toxoplasma gondii infection in the United States: seroprevalence and risk factors. Am J Epidemiol. 2001; 154:357-65. | Article | PubMed

2. Soares JAS, Násser LS, Carvalho, SFG, Caldeira, AP. Achados oculares em crianças com toxoplasmose congênita. Arq Bras Oftalmol. 2011; 74:2557. | Article

3. Lafferty KD. Look what the cat dragged in: do parasites contribute to human cultural diversity? Behav Processes. 2005; 68:279-82. | Article | PubMed

4. Groer MW, Yolken RH, Xiao JC, Beckstead JW, Fuchs D, Mohapatra SS, Seyfang A and Postolache TT. Prenatal depression and anxiety in Toxoplasma gondii-positive women. Am J Obstet Gynecol. 2011; 204:433 e1-7. | Article | PubMed Abstract | PubMed FullText

5. Campello Porto $L$ and Duarte EC. Association between the risk of congenital toxoplasmosis and the classification of toxoplasmosis in pregnant women and prenatal treatment in Brazil, 1994-2009. Int J Infect Dis. 2012; 16:e480-6. | Article | PubMed

6. Faucher B, Garcia-Meric P, Franck J, Minodier P, Francois P, Gonnet S, L'Ollivier $C$ and Piarroux $R$. Long-term ocular outcome in congenital toxoplasmosis: a prospective cohort of treated children. J Infect. 2012; 64:104-9. | Article | PubMed

7. Lopes-Mori FM, Mitsuka-Bregano R, Bittencourt LH, Dias RC, Goncalves DD, Capobiango JD, Reiche EM, Morimoto HK, Freire RL and Navarro IT. Gestational toxoplasmosis in Parana State, Brazil: prevalence of IgG antibodies and associated risk factors. Braz J Infect Dis. 2013; 17:405-9. | Article | PubMed

8. Fernandes MA, Batista GI, Carlos Jda C, Gomes IM, Azevedo KM, Setubal S, Oliveira SA, Velarde LG and Cardoso CA. Toxoplasma gondii antibody profile in HIV-1-infected and uninfected pregnant women and the impact on congenital toxoplasmosis diagnosis in Rio de Janeiro, Brazil. Braz J Infect Dis. 2012; 16:170-1174. | Article | PubMed

9. Dubey JP, Lago EG, Gennari SM, Su C and Jones JL. Toxoplasmosis in humans and animals in Brazil: high prevalence, high burden of disease, and epidemiology. Parasitology. 2012; 139:1375-424. | Article | PubMed

10. Fernandes MA, Batista GI, Carlos Jda C, Gomes IM, Azevedo KM, Setubal S, Oliveira SA, Velarde LG and Cardoso CA. Toxoplasma gondii antibody profile in HIV-1-infected and uninfected pregnant women and the impact on congenital toxoplasmosis diagnosis in Rio de Janeiro, Brazil. Braz J Infect Dis. 2012; 16:170-1174. | Article | PubMed

11. Hermida Perez JA, Hernandez AB and Gutierrez RS. Manifestaciones oftalmológicas de la infección por toxoplasma en paciente portador del virus de la inmunodeficiencia humana. Descripción de un caso. Medicina de Família SEMERGEN. 2013; (in press). I Article

12. dos Santos TR, Nunes CM, Luvizotto MC, de Moura AB, Lopes WD, da Costa AJ and Bresciani KD. Detection of Toxoplasma gondii oocysts in environmental samples from public schools. Vet Parasitol. 2010 171:53-7. | Article | PubMed

13. Gomez-Marin JE, de-la-Torre A, Barrios P, Cardona N, Alvarez C and Herrera C. Toxoplasmosis in military personnel involved in jungle operations. Acta Trop. 2012; 122:46-51. | Article | PubMed

14. Bonametti AM, Passos JN, Silva EMK and Bortoliero AL. Surto de Toxoplasmose aguda transmitida através da ingestão de carne crua de gado ovino. Rev Soc Bras Med Trop. 1997; 30:21-5. | Article |

15. Perna C, Rodrigues-Figueira Y, Morales C, Rodríguez J I, Hardisson D and Viguer JM. Revisión de casos con diagnóstico de toxoplasmosis en el Hospital La Paz de Madrid (1967-2010). Rev Esp Patol. 2012; 45:5-13. | Article

16. Ferguson DJ, Bowker C, Jeffery KJ, Chamberlain P and Squier W. Congenital toxoplasmosis: continued parasite proliferation in the fetal brain despite maternal immunological control in other tissues. Clin Infect Dis. 2013; 56:204-8. | Article | PubMed

17. Prandota J. Autism spectrum disorders may be due to cerebral toxoplasmosis associated with chronic neuroinflammation causing persistent hypercytokinemia that resulted in an increased lipid peroxidation, oxidative stress, and depressed metabolism of endogenous and exogenous substances. Res. Autismo Spectrum Disorders. 2010; 5:119-155. | Article

18. Prandota J. Metabolic immune, epigenetic, endocrine and phenotypic abnormalities found in individuals with autism spectrum disorders, Down Syndrome and Alzheimer Disease may be caused by congenital and/or acquired chronic cerebral toxoplasmosis. Res. Autismo Spectrum Disorders. 2011; 5:14-59. | Article

19. Garcia LC. Toxoplasma gondii. In A.S.M. Press, Diagnosis Medical Parasitology. 2007; 562-63. | Book

20. Dubey JP. Toxoplasmosis. J Am Vet Med Assoc. 1986; 189:166-70. | PubMed

21. Dubey JP, Greene CE, Lappin MR. Toxoplasmosis and Neosporosis. In Greene CE, Infectious diseases of the dog and cat. 1990; 818-34. | Book

22. Dubey JP. Toxoplasmosis. JAAMA. 1994; 205:1593-98. | Website

23. Tenter AM, Heckeroth AR and Weiss LM. Toxoplasma gondii: from animals to humans. Int J Parasitol. 2000; 30:1217-58. | Article | PubMed Abstract | PubMed FullText

24. Powell CC, Brewer M and Lappin MR. Detection of Toxoplasma gondii in the milk of experimentally infected lactating cats. Vet Parasitol. 2001; 102:29-33. | Article | PubMed

25. Kawazoe U. Toxoplasma gondii. In Neves DP, Parasitologia Humana. 2002; 147-56

26. Miller NL, Frenkel JK and Dubey JP. Oral infections with Toxoplasma cysts and oocysts in felines, other mammals, and in birds. $J$ Parasitol. 1972; 58:928-37. | Article | PubMed 
Bresciani et al. Research Journal of Infectious Diseases 2013, http://www.hoajonline.com/journals/pdf/2052-5958-1-7.pdf

27. Dubey JP. Toxoplasmosis and neosporosis. In Greene CE, Infectious diseases of the dog and cat. 1998; 493-03.

28. Benson VS, Green J and Beral V. The relationship between owning a cat and the risk of developing a brain cancer in a prospective study of UK women: comment on Thomas et al. Biol Lett. 2012; 8:1040-1; author reply 1042. | Article | PubMed

29. Caballero-Ortega H, Uribe-Salas FJ, Conde-Glez CJ, Cedillo-Pelaez C, Vargas-Villavicencio JA, Luna-Pasten $\mathrm{H}$, Canedo-Solares I, Ortiz-Alegria LB and Correa D. Seroprevalence and national distribution of human toxoplasmosis in Mexico: analysis of the $\mathbf{2 0 0 0}$ and 2006 National Health Surveys. Trans R Soc Trop Med Hyg. 2012; 106:653-9. | Article | PubMed

30. Chiari CA and Neves DP. Toxoplasmose humana adquirida através da ingestão de leite de cabra. Mem Inst Oswaldo Cruz 1984; (79) 337-40.

31. Bowie WR, King AS, Werker DH, Isaac-Renton JL, Bell A, Eng SB and Marion SA. Outbreak of toxoplasmosis associated with municipal drinking water. The BC Toxoplasma Investigation Team. Lancet. 1997; 350:173-7. | Article | PubMed

32. Fundação Nacional de Saúde-FUNASA. Boletim Eletrônico Epidemiológico 2003. I Website

33. Almeida MJ, Oliveira, LHH, Freire, RL and Navarro, RT. Aspectos sociopolíticos da epidemiologia de toxoplasmose em Santa Isabel do Ivaí (PR). Ciênc Saúde Coletiva. 2011; 16:1363-73. | Pdf

34. Monteiro SG. In Editora Roca, Parasitologia na Medicina Veterinária 2010; 370p.

35. Garcia-Bocanegra I, Cabezon O, Arenas-Montes A, Carbonero A, Dubey JP, Perea A and Almeria S. Seroprevalence of Toxoplasma gondii in equids from Southern Spain. Parasitol Int. 2012; 61:421-4. | Article | PubMed

36. Villena I, Durand B, Aubert D, Blaga R, Geers R, Thomas M, Perret C, Alliot A, Escotte-Binet S, Thebault A, Boireau P and Halos L. New strategy for the survey of Toxoplasma gondii in meat for human consumption. Vet Parasitol. 2012; 183:203-8. | Article | PubMed

37. Jones JL and Dubey JP. Foodborne toxoplasmosis. Clin Infect Dis. 2012; 55:845-51. | Article | PubMed

38. Ross DS, Rasmussen SA, Cannon MJ, Anderson B, Kilker K, Tumpey A, Schulkin J and Jones JL. Obstetrician/gynecologists' knowledge, attitudes, and practices regarding prevention of infections in pregnancy. J Womens Health (Larchmt). 2009; 18:1187-93. | Article | PubMed.

39. Cárdia DFF, Amarante AFT and Bresciani KDS. Ponto de vista de professoras de escolas municipais do ensino fundamental de Araçatuba (SP) sobre as parasitoses. Rev Ciên Exten. 2007; 3:43-55. | Article

40. Lima FF, Koivisto MB, Perri SHV and Bresciani KDS. O conhecimento de idosos sobre parasitoses em instituições não governamentais do Município de Araçatuba- SP. Rev Ciên Exten. 2008; 4:77-85. | Article

41. Tomé RO, Serrano ACM, Nunes CM, Perri SHV and Bresciani KDS. Inquérito epidemiológico sobre conceitos de zoonoses parasitárias para professores de escolas municipais do ensino infantil de Araçatuba-SP. Rev Ciên Exten. 2005; 2:1-11. | Article

42. Bresciani KDS, Galvão ALB, Vasconcellos AL, Silveira Neto L, Inácio SV, Soares JA, Gomes JF, Santos TR, Santos, RR. In Nova Publishers, New York. Toxoplasmosis in public health. Toxoplasma gondii: Prevalence in Humans and Animals, Genetic Structure and Role in Disease Distribution 2013a (in press).

43. Bresciani KDS, Cardia DFF, Camossi LG, Galvão ALB, Vasconcellos AL, Santos RR, Santos TR and Soares, JA. Need for a continuing education program for toxoplasmosis control. Educ J. 2013; 2:114-118. | Pdf

44. Ekman CC, Chiossi MF, Meireles LR, Andrade Junior HF, Figueiredo WM, Marciano MA and Luna EJ. Case-control study of an outbreak of acute toxoplasmosis in an industrial plant in the state of Sao Paulo, Brazil. Rev Inst Med Trop Sao Paulo. 2012; 54:239-44. | Article | PubMed

45. Eskild Petersen. Toxoplasmosis. Seminars in Fetal \& Neonatal Medicine. 2007; 12:214-223. | Article

46. Aspock H. Prevention of congenital toxoplasmosis in Austria. Arch Pediatr. 2003; 10 Suppl 1:16-7. I PubMed

47. Rilling V, Dietz K, Krczal D, Knotek F and Enders G. Evaluation of a commercial IgG/IgM Western blot assay for early postnatal diagnosis of congenital toxoplasmosis. Eur J Clin Microbiol Infect Dis. 2003; 22:17480. | PubMed

48. Centers for Disease Control and Prevention. Preventing congenital toxoplasmosis. MMWR Recomm Rep. 2000; 49:57-75. | Website

49. Guidelines for Prevention and Treatment of Opportunistic Infections in HIV-Infected Adults and Adolescents. Recommendations from CDC, the National Institutes of Health, and the HIV Medicine Association of the Infectious Diseases Society of America. 2009; 58(RR04)1-198. I Website

50. Jones JL and Roberts JM. Toxoplasmosis hospitalizations in the United States, 2008, and trends, 1993-2008. Clin Infect Dis. 2012; 54:e58-61. | Article | PubMed

51. Minbaeva G, Schweiger A, Bodosheva A, Kuttubaev O, Hehl AB, Tanner I, Ziadinov I, Torgerson PR and Deplazes P. Toxoplasma gondii infection in Kyrgyzstan: seroprevalence, risk factor analysis, and estimate of congenital and AIDS-related toxoplasmosis. PLoS Negl Trop Dis. 2013; 7:e2043. | Article | PubMed Abstract | PubMed FullText

52. Baquero-Artigao F, Martín FC, Fuentes Corripio I, Goncé Mellgren A, Fortuny Guasch C, Fernández-Miranda MC, González-Tomé MI, Gianzo JAC, Neth $\mathrm{O}$ and Ramos Amador, JT. Guía de la Sociedad Espanola de Infectología Pediátrica para el diagnóstico y tratamiento de la toxoplasmosis congénita. An Pediatr, 2013. | Article | Website

53. Chintapalli $S$ and Padmaja IJ. Seroprevalence of toxoplasmosis in antenatal women with bad obstetric history. Trop Parasitol. 2013; 3:626. | Article | PubMed Abstract | PubMed FullText

54. Amin TT, Al Ali MN, Alrashid AA, Al-Agnam AA and Al Sultan AA. Toxoplasmosis Preventive Behavior and Related Knowledge among Saudi Pregnant Women: An Exploratory Study. Glob J Health Sci. 2013; 5:131-43. | Article | PubMed

55. Mittal V and Ichhpujani RL. Toxoplasmosis - An update. Trop Parasitol. 2011; 1:9-14. | PubMed Abstract | PubMed FullText

56. Hotop A, Hlobil $\mathrm{H}$ and Gross U. Efficacy of rapid treatment initiation following primary Toxoplasma gondii infection during pregnancy. Clin Infect Dis. 2012; 54:1545-52. | Article | PubMed

57. Yu L, Yamagishi J, Zhang S, Jin C, Aboge GO, Zhang H, Zhang G, Tanaka T, Fujisaki K, Nishikawa $Y$ and Xuan X. Protective effect of a prime-boost strategy with plasmid DNA followed by recombinant adenovirus expressing TgAMA1 as vaccines against Toxoplasma gondii infection in mice. Parasitol Int. 2012; 61:481-6. | Article | PubMed

58. Quan JH, Chu JQ, Ismail HA, Zhou W, Jo EK, Cha GH and Lee YH. Induction of protective immune responses by a multiantigenic DNA vaccine encoding GRA7 and ROP1 of Toxoplasma gondii. Clin Vaccine Immunol. 2012; 19:666-74. | Article | PubMed Abstract | PubMed FullText

\section{Citation:}

Bresciani KDS, Galvão ALB, Vasconcellos ALd, Soares JA, Matos LVSd, Pierucci JC, Neto LdS, Rodrigues TO, Navarro IT, Gomes JF and Costa AJd. Relevant aspects of human toxoplasmosis. Res J Infect Dis. 2013; 1:7. http://dx.doi.org/10.7243/2052-5958-1-7 